\title{
Thermophilic 4--Glucanotransferase from Thermoproteus Uzoniensis Retards the Long-Term Retrogradation but Maintains the Short-Term Gelation Strength of Tapioca Starch
}

Wang, Yu; Li, Xiaoxiao; Ji, Hangyan; Zheng, Danni; Jin, Zhengyu; Bai, Yuxiang; Svensson, Birte

Published in:

Journal of Agricultural and Food Chemistry

Link to article, DOI:

10.1021/acs.jafc.0c00927

Publication date:

2020

Document Version

Peer reviewed version

Link back to DTU Orbit

Citation (APA):

Wang, Y., Li, X., Ji, H., Zheng, D., Jin, Z., Bai, Y., \& Svensson, B. (2020). Thermophilic 4--Glucanotransferase from Thermoproteus Uzoniensis Retards the Long-Term Retrogradation but Maintains the Short-Term Gelation Strength of Tapioca Starch. Journal of Agricultural and Food Chemistry, 68(20), 5658-5667. https://doi.org/10.1021/acs.jafc.0c00927

\section{General rights}

Copyright and moral rights for the publications made accessible in the public portal are retained by the authors and/or other copyright owners and it is a condition of accessing publications that users recognise and abide by the legal requirements associated with these rights.

- Users may download and print one copy of any publication from the public portal for the purpose of private study or research.

- You may not further distribute the material or use it for any profit-making activity or commercial gain

- You may freely distribute the URL identifying the publication in the public portal 
J O U R N A L O F

Subscriber access provided by BIU Pharmacie | Faculté de Pharmacie, Université Paris V

\section{Biotechnology and Biological Transformations}

\section{A Thermophilic 4-\#-Glucanotransferase from Thermoproteus Uzoniensis Retards the Long-Term Retrogradation but Maintains the Short-Term Gelation Strength of Tapioca Starch}

Yu Wang, xiaoxiao li, Hangyan Ji, Danni Zheng, Zhengyu Jin, Yuxiang Bai, and Birte Svensson J. Agric. Food Chem., Just Accepted Manuscript • Publication Date (Web): 30 Apr 2020

Downloaded from pubs.acs.org on April 30, 2020

\section{Just Accepted}

"Just Accepted" manuscripts have been peer-reviewed and accepted for publication. They are posted online prior to technical editing, formatting for publication and author proofing. The American Chemical Society provides "Just Accepted" as a service to the research community to expedite the dissemination of scientific material as soon as possible after acceptance. "Just Accepted" manuscripts appear in full in PDF format accompanied by an HTML abstract. "Just Accepted" manuscripts have been fully peer reviewed, but should not be considered the official version of record. They are citable by the Digital Object Identifier (DOI®). "Just Accepted" is an optional service offered to authors. Therefore, the "Just Accepted" Web site may not include all articles that will be published in the journal. After a manuscript is technically edited and formatted, it will be removed from the "Just Accepted" Web site and published as an ASAP article. Note that technical editing may introduce minor changes to the manuscript text and/or graphics which could affect content, and all legal disclaimers and ethical guidelines that apply to the journal pertain. ACS cannot be held responsible for errors or consequences arising from the use of information contained in these "Just Accepted" manuscripts. 


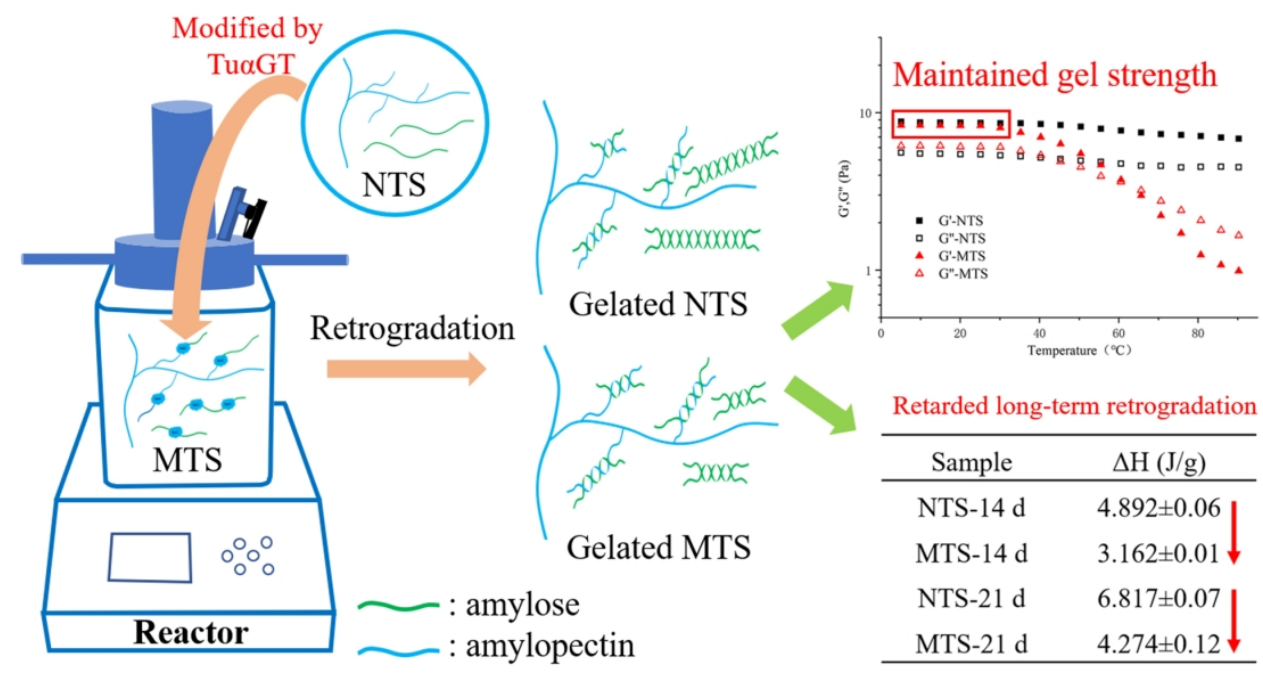

Abstract Graphic

$84 \times 44 \mathrm{~mm}(600 \times 600 \mathrm{DPI})$ 


\section{A Thermophilic 4- $\alpha$-Glucanotransferase from Thermoproteus Uzoniensis Retards the Long-Term}

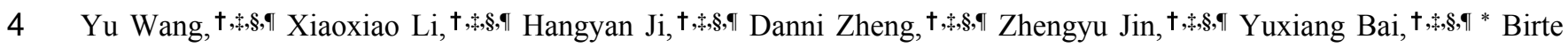

5 Svensson"

6 † State Key Laboratory of Food Science and Technology, Jiangnan University, Wuxi, Jiangsu 214122, China;

$7 \quad \ddagger$ School of Food Science and Technology, Jiangnan University, Wuxi, Jiangsu 214122, China;

8 § Synergetic Innovation Center of Food Safety and Nutrition, Jiangnan University, Wuxi 214122, China;

9 I International Joint Laboratory on Food Safety, Jiangnan University, Wuxi, Jiangsu 214122, China;

10 II Enzyme and Protein Chemistry, Department of Biotechnology and Biomedicine, Technical University of Denmark,

11 DK-2800 Kgs. Lyngby, Denmark

12

${ }^{*}$ Corresponding author at: State Key Laboratory of Food Science and Technology, Jiangnan University, Wuxi, Jiangsu

13

214122, China.

14

E-mail address: ybai@jiangnan.edu.cn

15

Tel number: $+86-0510-85329291$

16 
17 ABSTRACT: Gelation of starch is a process during short-term retrogradation. However, the long-term retrogradation always leads to the quality deterioration of starch-based food. In this work, a new type of modified tapioca starch (MTS) gel with maintained starch short-term gelation strength and retarded long-term retrogradation was prepared using a novel recombinantly produced and characterized 4- $\alpha$-glucanotransferase (Tu $\alpha \mathrm{GT})$. In the resulting MTS exterior chains of the amylopectin part were elongated and the content of amylose was reduced, due to the disproportionation activity of TuaGT.

The retrogradation analysis demonstrated that the MTS possessed highly weakened long-term retrogradation characteristics as compared to the native starch. Most importantly, the strength of the gel formed by re-gelatinized MTS is very close to that of gelatinized native tapioca starch (NTS) when storing below $30^{\circ} \mathrm{C}$. These findings provide a starting point for developing a novel method for the enzymatic modification of the starch-based gels.

KEYWORDS: long-term retrogradation, gel properties, starch-based gel, 4- $\alpha$-glucanotransferase

(n)

\section{INTRODUCTION}

Retrogradation is an important functional attribute in starch-based foods. In this process unordered starch molecules in an amorphous phase transfer to a more ordered crystalline state. ${ }^{1}$ This transformation can be divided into two stages, the short-term and the long-term retrogradation. Short-term retrogradation, namely gelation that is beneficial for strengthening the texture of starch-based foods, such as bread, steam bread, noodles etc., is mainly attributed to the aggregation of amylose. ${ }^{2}$ However, further reassociation of amylose with amylose as well as amylopectin molecules would lead to long-term retrogradation that causes a decline in the taste of starch-based foods. ${ }^{3}$

Many studies have been conducted to inhibit or delay the long-term retrogradation of starch. ${ }^{4,5}$ Among the various current treatments, enzymatic modification was preferred over chemical modification, as this provides products having the "clean-label" advantage. ${ }^{6}$ Reduction in amylose content or breakdown of amylose into shorter fragments by endoand exo-acting enzymes, such as $\alpha$-amylase, ${ }^{7} \beta$-amylase ${ }^{8}$ and so on, represents by far the most efficient type of 
approaches. However, typically enzymatic modifications also impaired the short-term retrogradation properties, resulting

in weaker gel strength and poorer chewability. ${ }^{9}$ Another option may be to use waxy starches only containing amylopectin,

but waxy starch hardly forms a solid gel during short-term retrogradation, which severely limits its application. Indeed, many studies focused on enhancing starch gel strength during short-term retrogradation by using enzymatic treatments. ${ }^{10}$ These include the action of starch debranching enzymes such as pullulanase and isoamylase hydrolyzing branch points in amylopectin with release of short amylose fragments, clearly improving the gelation property of starch. ${ }^{11}$ But the longterm retrogradation of partially debranched starch became seriously disadvantageous during storage. ${ }^{10}$ Thus, the shortterm retrogradation advantage and the long-term retrogradation disadvantage can co-occur and be positively correlated.

The aim to reduce the harmful effect of long-term retrogradation and keep the short-term gel formation as strong as possible, by strengthening the gelation property of amylopectin and weaken the contribution of the amylose part would

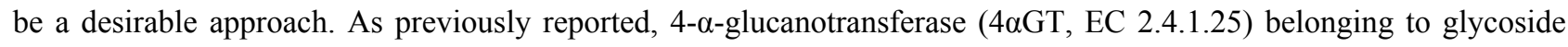
hydrolase family 77 (GH77) catalyzes disproportionation reactions cleaving amylose into shorter fragments which are transferred to the non-reducing ends of amylopectin resulting in longer exterior chains. ${ }^{12} 4 \alpha \mathrm{GT}$ has been successfully applied in preparation of thermo-reversible starch gels, proving the reassociation of amylose to be strongly eliminated. ${ }^{13}$ Thus, $4 \alpha \mathrm{GT}$ offers a potential solution to reach a better balance between short-term and long-term retrogradation.

In the present study, a new type of modified tapioca starch (MTS) gel with maintained starch short-term gelation

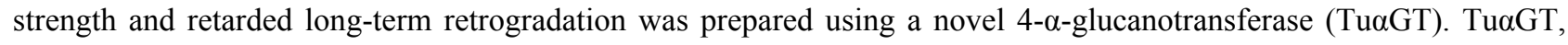
discovered from a new archebacterium Thermoproteus uzoniensis sharing rather low identity, i.e. maximum similarity of 64.74\% with 4 $\alpha$ GT from Pyrobaculum arsenaticum DSM 13514 (GenBank accession number ABP49821.1)), was cloned

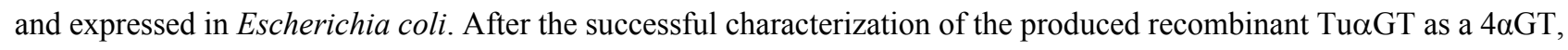
tapioca starch was chosen for the enzymatic modification. The structure determination, retrogradation analysis and rheological test showed that the $4 \alpha \mathrm{GT}$ treatment indeed changed the starch structure in a remarkable way, resulting in a reduced long-term retrogradation but maintaining most of the gel strength compared to native tapioca starch. Therefore, 

value.

\section{MATERIALS AND METHODS}

Materials. Maltotriose and maltotetraose were purchased from Sigma-Aldrich Co. Ltd (St. Louis, MO, USA). Tapioca starch was kindly provided by STARPRO Co. Ltd (Hangzhou, China, amylose content 23\%). Isoamylase (from Pseudomonas sp., EC 3.2.1.68, specific activity $500 \mathrm{U} / \mathrm{mL}$ ), $\alpha$-amylase (from Aspergillus oryzae, EC 3.2.1.1, specific activity $120 \mathrm{U} / \mathrm{mg}$ ) and $\alpha$-glucosidase (from Aspergillus niger, EC 3.2.1.20, specific activity $70 \mathrm{U} / \mathrm{mg}$ ) were purchased from Megazyme Co. Ltd (Wicklow, Ireland). Dextran standards of $8.53 \times 10^{6}, 8.53 \times 10^{5}, 6.7 \times 10^{5}, 5 \times 104,2.5 \times 10^{4} \mathrm{Da}$ (polydispersity 1.047) were purchased from Aladdin Co. Ltd (Shanghai, China). All other chemicals were of reagent grade and purchased from China National Pharmaceutical Group Corporation (Beijing, China).

Cloning and Preparation of 4aGT from Thermoproteus uzoniensis (TuaGT). Cloning of $4 \alpha \mathrm{GT}$ was conducted following the method reported by Yu et al. ${ }^{14}$ The nucleotide sequence of the $4 \alpha \mathrm{GT}$ gene from Thermoproteus uzoniensis (GenBank accession number WP_013679179.1) was cloned into the expression vector pET-28a (+) with kanamycin resistance gene after digestion with NdeI and HindIII to construct the recombinant plasmid. A $6 \times$ histidine-tag was designed and inserted into the N-terminus for the purification of enzyme. The recombined plasmid was transferred into Escherichia coli BL21 (DE3)* for further protein production by the Beijing Liuhe Huada Gene Technology Company (Beijing, China). Strains E. coli DH5 $\alpha$ and E. coli BL21 (DE3) were selected as hosts for the cloning and expression of TuaGT gene, respectively. recombinant E.coli BL21 (DE3)* was cultivated in LB medium containing kanamycin $(50 \mu \mathrm{g} / \mathrm{mL})$ at $37^{\circ} \mathrm{C}$ with shaking at $200 \mathrm{rpm}$. The expression of recombined protein was performed at $18^{\circ} \mathrm{C}$ with shaking at $160 \mathrm{rpm}$ for $24 \mathrm{~h}$ by adding 
0.6. The cells were collected by centrifugation $(10,000 \times g$ for $15 \mathrm{~min})$ and then disrupted by sonication in an ice bath.

Purification of the Recombinant Enzyme. After incubation at $60^{\circ} \mathrm{C}$ for $20 \mathrm{~min}$ followed by centrifugation $(10,000 \times$ $g$ for $30 \mathrm{~min}$ ) to remove thermolabile non-target protein, the enzyme was purified from the supernatant by Ni-NTA affinity chromatography (GE Healthcare). The recombined protein was eluted by $250 \mathrm{mM}$ imidazole in $20 \mathrm{mM}$ Tris-HCl buffer (pH 7.5) containing $250 \mathrm{mM} \mathrm{NaCl}$. The purified protein was analyzed by sodium dodecylsulfate-polyacrylamide gel electrophoresis (SDS-PAGE). The proteins in each purification step were quantified by a BCA Protein Assay Kit (Beyotime Biotechnology, Shanghai, China) using BSA as the standard. In total $2.4 \mathrm{mg}$ of TuaGT was purified from $2 \mathrm{~L}$ of culture. ${ }^{16}$

Disproportionation Activity Assay. The disproportionation activity of TuaGT was determined following the method reported by $\mathrm{Yu}$ et al. ${ }^{17}$ by incubating $1 \%$ maltooligosaccharides (maltose (G2), maltotriose (G3) and maltotetraose (G4)) in $900 \mu \mathrm{L}$ assay buffer $(50 \mathrm{mM}, \mathrm{pH} 6.0$ sodium citrate buffer $)$ with $100 \mu \mathrm{L}$ TuaGT $(0.2 \mathrm{~g} / \mathrm{mL})$ at $75^{\circ} \mathrm{C} 6$ h. The rate of glucose released was determinated by high performance liquid chromatography (HPLC) using a Shimadzu LC-20AT pump, a Rheodyne injector and a Shimadzu RID-10A detector, equipped with an Ultimate XB-NH2 column at $30^{\circ} \mathrm{C}$ using as mobile phase acetonitrile: ultrapure water $(7: 3, \mathrm{v} / \mathrm{v})$ at a flow rate of $1 \mathrm{~mL} / \mathrm{min} .{ }^{14}$ One unit of disproportionation activity was defined as the amount of enzyme which released $1 \mu \mathrm{mol}$ of glucose per minute under the above conditions.

Effects of Temperature, $\mathbf{p H}$ and Metal Ions on the Activity of TuaGT. To determine the pH optimum of TuaGT, the activity was assayed in $50 \mathrm{mM}$ sodium citrate buffer ( $\mathrm{pH} 4.0-5.5)$, phosphate buffer ( $\mathrm{pH}$ 6.0-8.0) and glycine-NaOH $\left(\mathrm{pH} 8.5-10.0\right.$ ) at $75^{\circ} \mathrm{C} .{ }^{15}$ The activity of the enzyme at the $\mathrm{pH}$ optimum was defined as $100 \%$. TuaGT activity was determined at different temperatures $\left(50-90^{\circ} \mathrm{C}\right)$ to identify the temperature optimum at $\mathrm{pH}$ 6.0. To determine the thermostability, TuaGT $(0.2 \mathrm{mg} / \mathrm{mL})$ was incubated at different temperatures $\left(60-100^{\circ} \mathrm{C}\right)$ at $\mathrm{pH} 6.0$ for $4 \mathrm{~h}$, and the residual enzyme activity was measured at $1 \mathrm{~h}$ intervals. The enzyme activity without incubation was defined as $100 \%$ stability.

Different metal ions $\left(\mathrm{K}^{+}, \mathrm{Na}^{+}, \mathrm{Cu}^{2+}, \mathrm{Ca}^{2+}, \mathrm{Fe}^{3+}, \mathrm{Mg}^{2+}, \mathrm{Mn}^{2+}\right.$ ) were each added to assay buffer (50 mM, pH 6.0 sodium 
citrate buffer) to a resulting concentration of $5 \mathrm{mM}$ and TuaGT (final concentration $0.1 \mathrm{mg} / \mathrm{mL}$ ) was added to each metal ion solution and incubated at $4{ }^{\circ} \mathrm{C}$ for $1 \mathrm{~h} .{ }^{18}$ Tu $\alpha \mathrm{GT}$ in buffer without metal ion was used as a control and residual activity after metal ion incubation was determined using the disproportionation activity assay.

Substrates Specificity of TuaGT. The substrate specificity of TuaGT was determined by incubating with glucose, maltose, maltotriose, or maltotetraose as substrate $\left(1 \%\right.$, w/v) in $50 \mathrm{mM}$ sodium citrate buffer at $75^{\circ} \mathrm{C}$ and $\mathrm{pH} 6.0$ for $6 \mathrm{~h}$.

To determine the type of glycosidic linkage of the product, 0.5 unit of $\alpha$-amylase (from Aspergillus oryzae) and 1 unit of $\alpha$-glucosidase (from Aspergillus niger) were added to the obtained product, followed by incubation at $40^{\circ} \mathrm{C}$ and $\mathrm{pH} 5.0$ for $1 \mathrm{~h}$. The formed products were analyzed by HPLC using a Shimadzu LC-20AT pump, a Rheodyne injector and a Shimadzu RID-10A detector, equipped with an Ultimate $\mathrm{XB}-\mathrm{NH} 2$ column at $30^{\circ} \mathrm{C}$ using as mobile phase acetonitrile: ultrapure water $(7: 3, \mathrm{v} / \mathrm{v})$ at a flow rate of $1 \mathrm{~mL} / \mathrm{min}^{14}$

Preparation of Modified Tapioca Starch (MTS). Enzymatic modification of tapioca starch was performed following the method reported by Lee et al. ${ }^{19}$ Dry starch powder (6\%, w/v) was suspended in $20 \mathrm{mM}$ sodium citrate buffer (pH 6.0), followed by gelatinization at $121^{\circ} \mathrm{C}$ for 30 min while stirring. The modification was carried out by incubating with 0.12 mg TuaGT per $1 \mathrm{~g}$ of starch at $75^{\circ} \mathrm{C}$ for $8 \mathrm{~h}$, and terminated by heating at $100^{\circ} \mathrm{C}$ for $30 \mathrm{~min}$. The modified starch was precipitated by adding three volumes of ethanol and dried at $40^{\circ} \mathrm{C}$ for $8 \mathrm{~h}$ after collecting by centrifugation ( $5000 \mathrm{rpm}$ for $10 \mathrm{~min})$.

Amylose Content. The amylose content of tapioca starch during the modification was determined by Megazyme KAMYL kit method. ${ }^{20}$ Concanavalin A was used to precipitate the amylopectin by complex formation. After being hydrolyzed by a glucoamylase/ $\alpha$-amylase mixture, the amylose content was obtained as calculated from the converted glucose quantified using the GOPOD method.

Retrogradation Properties. Retrogradation of native tapioca starch (NTS) and MTS was examined by measuring the melting onset $\left(T_{0}\right)$, peak $\left(T_{p}\right)$, conclusion $\left(T_{c}\right)$ temperature and melting enthalpy $(\Delta \mathrm{H})$ using a DSC7000 calorimeter (HITACHI, Japan). Three milligrams of NTS and MTS were mixed with $6 \mu \mathrm{L}$ deionized water and hermetically sealed 
in an aluminium pan. ${ }^{21}$ The samples were placed at room temperature $\left(25^{\circ} \mathrm{C}\right)$ overnight and then tested from 20 to $100^{\circ} \mathrm{C}$ at a rate of $10^{\circ} \mathrm{C} / \mathrm{min}$ with an empty aluminum pan as reference. Melting enthalpy $(\Delta \mathrm{H})$ was calculated from the area of the main endothermic peak and expressed in terms of $\mathrm{J} / \mathrm{g}$ of dry starch using the equipment software.

Chain Distribution of Debranched Starch. Chain distribution of starch was determined according to our previous work with some modifications. ${ }^{22}$ High performance anion exchange chromatography with pulsed amperometric detection (HPAEC-PAD) was used to analysis the chain length distribution of starch. Two mg/mL dry solid (w/v) starch was suspended in $50 \mathrm{mM}$ sodium acetate buffer ( $\mathrm{pH} 4.5$ ), followed by gelatinization on a boiling water bath for $30 \mathrm{~min}$. The gelatinized starch was debranched by incubation with $2 \mathrm{U}$ of isoamylase per $1 \mathrm{mg}$ of starch at $42^{\circ} \mathrm{C}$ for $12 \mathrm{~h}$. The obtained reaction mixtures were analyzed by HPAEC-PAD (ICS-5000+, Thermo Fisher Scientific, USA). Samples $(20 \mu \mathrm{L})$ were injected onto a CarboPac PA-200 column at $0.6 \mathrm{~mL} / \mathrm{min}$ flow rate. The average DP was calculated from the corrected values of the relative content of each chain. ${ }^{23}$

Molecular Weight of NTS and MTS. Size Exclusion Chromatography-Multi-Angle Laser Light Scattering-Refractive Index Detector (SEC-MALLS-RI) was used to analysis the molecular weight of NTS and MTS samples according to the previous work. ${ }^{24}$ The calibration of the instrument was carried out with dextran standards $\left(8.53 \times 10^{6}, 8.53 \times 10^{5}, 6.7 \times 10^{5}\right.$, $5 \times 10^{4}, 2.5 \times 10^{4} \mathrm{Da}$, polydispersity 1.047 , Aladdin, China $)$ which were solubilized in MilliQ water $(1 \mathrm{mg} / \mathrm{mL})$ and treated on a boiling water bath for $1 \mathrm{~h}$. Dry starch $(5 \mathrm{mg} / \mathrm{mL})$ was suspended in a mixture of DMSO and ultrapure water (9:1, $\mathrm{v} / \mathrm{v}$ ), followed by gelatinization on a boiling water bath for $1 \mathrm{~h}$ and shaking every $10 \mathrm{~min}$ until the solution becomes clear and free of floc. The gelatinized starch was incubated at $30^{\circ} \mathrm{C}$ in a shaker with $250 \mathrm{rpm}$ for $48 \mathrm{~h}$ to disrupt the starch granules. Then the samples were re-boiled and filtered through a $0.45 \mu \mathrm{m}$ filter (MAISINUO, China). Filtrate (100 $\mu \mathrm{l}$ ) was injected on a tandem column (Ohpak SB-804 HQ, Ohpak SB-806 HQ) using $0.1 \mathrm{M} \mathrm{NaNO}_{3}\left(0.02 \% \mathrm{NaN}_{3}\right)$ as mobile phase at a flow rate of $0.6 \mathrm{~mL} / \mathrm{min}$. The column temperature was set at $50^{\circ} \mathrm{C}$. Data obtained from the MALLS and RI detectors were analyzed by ASTRA software version 5.3.4 (Wyatt Technologies). 
155 previous work ${ }^{21}$ and the method reported by van der Maarel et al..$^{12}$ with some modifications. Dry starch powder $(6 \%$, $156 \mathrm{w} / \mathrm{v}$ ) was suspended in deionized water, followed by gelatinization at $90^{\circ} \mathrm{C}$ for $30 \mathrm{~min}$ while stirring. The resulting starch solutions were transferred to a disposable petri dish (40 $\mathrm{mm}$ diameter) with a plastic wrap covered on the bottom and stored at $4^{\circ} \mathrm{C}$ for 7 days before the dynamic rheological tests. Dynamic rheological data on NTS and MTS were obtained using a Rheometer (TA Instruments, Waters LLC, USA) using a parallel-plate system (40 mm diameter) at a gap of 1000 $\mu \mathrm{m}$. Each sample was transferred to the rheometer plate with the plastic wrap at the desired temperature and then the plastic wrap was removed slowly. The surplus sample was wiped off with a spatula. Oscillation amplitude was obtained over an oscillation strain range of $0.1-100 \%$ at room temperature $\left(25^{\circ} \mathrm{C}\right)$ to detect the linear viscoelastic range. Dynamic shear data were obtained from frequency sweeps over the range of $0.1-100 \mathrm{rad} / \mathrm{s}$ in the linear viscoelastic range at room temperature $\left(25^{\circ} \mathrm{C}\right)$. The effect of temperature $\left(5-90^{\circ} \mathrm{C}\right)$ on storage modulus $\left(\mathrm{G}^{\prime}\right)$ and loss modulus $\left(\mathrm{G}^{\prime \prime}\right)$ was studied under steady increasing speed $\left(10^{\circ} \mathrm{C} / \mathrm{min}\right)$.

Statistical Analysis. The data were expressed as means of triplicate determinations. The statistical significance was assessed with one-way analysis of variance (ANOVA) using SPSS 20.0 (SPSS Inc., Chicago, USA) for windows program. p value $<0.05$ was considered to be statistically significant throughout the study.

\section{RESULTS AND DISCUSSION}

Sequence and Phylogenetic Analyses of TuaGT. The target protein sequence of Thermoproteus uzoniensis WP_013679179.1 was aligned with known 4aGT sequences using MEGA6 software (Figure 1A). The TuaGT sequence shared three conserved regions, three catalytic site key amino acid residues, and a characteristic 250 s loop with the enzyme homologues. Asp282 in conserved region I is the putative catalytic nucleophile, Glu323 in conserved region II the proton donor, and Asp382 of the conserved region III is transition state stabilizer. ${ }^{25}$ 
and +3 subsites. ${ }^{27,} 28$ Experiments have shown that the 250s loop has a role in both hydrolysis and transglycosylation activity. ${ }^{27}$ A BLAST comparison to the gene sequences in the NCBI database revealed that the TuaGT sequence only possessed up to $64.74 \%$ similarity to known $4 \alpha \mathrm{GTs}$. $\alpha$-amylase, pullulanase, and $4 \alpha \mathrm{GT}$ from different sources were selected to construct the phylogenetic tree (Figure 1B). The results illustrate that TuaGT of Thermoproteus uzoniensis was more closely related to other $4 \alpha \mathrm{GTs}$. Together the phylogenetic tree and the BLAST sequence alignment supported the preliminarily conclusion that the recombinantly produced enzyme (TuaGT) was a $4 \alpha \mathrm{GT}$.

Purification and Characterization of TuaGT. After heat treatment and Ni-NTA purification, a single protein band corresponding to molecular weight of about $57 \mathrm{kDa}$ was obtained by SDS-PAGE, consistent with $57.9 \mathrm{kDa}$ predicted by ExPasy website (Figure. 2A). As seen from Figure 2B and 2C, optimal pH and reaction temperature of TuaGT were 6.0 and $75^{\circ} \mathrm{C}$. TuaGT maintained more than $80 \%$ activity at $60 \sim 80^{\circ} \mathrm{C}$, indicating that TuaGT is a thermophilic enzyme. In Figure $2 \mathrm{D}$ is shown that after $4 \mathrm{~h}$ of heat treatment TuaGT maintained $>80 \%$ of the activity even at $80^{\circ} \mathrm{C}$. The activity, however, decreased significantly at $90^{\circ} \mathrm{C}$ with a half-life of $38.5 \mathrm{~min}$ compared to $690 \mathrm{~min}$ at $75^{\circ} \mathrm{C}$. When incubated

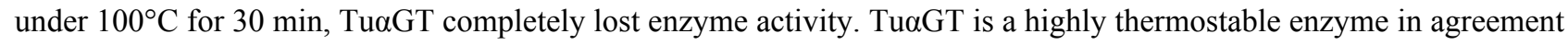
with its host strain Thermoproteus uzoniensis being alive above $90^{\circ} \mathrm{C}$ in the crater. ${ }^{29} \mathrm{To}$ determine the influence of metal ions on activity, TuaGT was incubated with metal ions at $4{ }^{\circ} \mathrm{C}$ for $1 \mathrm{~h}$ (Figure $2 \mathrm{E}$ ). $\mathrm{Cu}^{2+}, \mathrm{Mg}^{2+}$, and $\mathrm{Fe}^{2+}$ significantly reduced the enzyme activity, while $\mathrm{Ca}^{2+}$ slightly activated TuaGT and $\mathrm{Mn}^{2+}, \mathrm{Na}^{+}$, and $\mathrm{K}^{+}$hardly affected the activity of TuaGT.

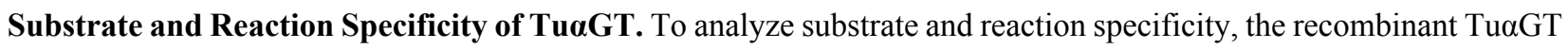
was incubated with various substrates including glucose, maltose, maltotriose or maltotetraose and the products were analyzed by HPLC. As can be seen from Figure 3 A, no product was formed with glucose as substrate, indicating that TuaGT was inactive on glucose alone. However, when maltose, maltotriose or maltotetraose were used as substrates, glucose was released by TuaGT in all cases. Importantly, a series of products with higher degree of polymerization (DP) than of the substrate were formed, demonstrating that TuaGT has disproportionation activity as reported for other 
$4 \alpha \mathrm{GTs} .{ }^{30}$ To determine whether the product of the disproportionation activity consisted of $\alpha-1,4$ linkages, $\alpha$-amylase and $\alpha$-glucosidase were used to hydrolyse the product. The two different enzymes both specifically hydrolyze $\alpha-1,4$ linkages and $\alpha$-glucosidase, only glucose was detected from the product, confirming that TuaGT has strong reaction specificity on forming $\alpha-1,4$ linkage by disproportionation. The smallest substrate of TuaGT is maltose, which is similar to that reported for $4 \alpha \mathrm{GT}$ from Thermus aquaticus. ${ }^{31}$ In conclusion, TuaGT has strong potential to act on and produce larger maltodextrins and modified starch molecules.

\section{Structure Analysis of the Modified Tapioca Starch (MTS) Compared with Native Tapioca Starch (NTS). To}

confirm the activity of TuaGT on starch, tapioca starch as one of the widely used starches was selected as substrate. After

the reaction with TuaGT, the structure of the product was elucidated by determining the chain length distribution,

to B-chains which have 6-12 glucose residues. The modification of tapioca starch by TuaGT had a very important effect on the structural properties. The content of chains in the MTS with DP $<10$ (A-chains) decreased significantly, and chains with DP $>10$ (B-chains) showed different degrees of increase in length. The content of chains of DP 10-30 (B-chains) clearly increased. According to the previous studies, ${ }^{12}$ this feature indicated that the exterior chains of amylopectin were elongated, this structure therefore would not fit with the regular definition of A, B and C-chains and probably also represent increases in the molecular weight $\left(\mathrm{M}_{\mathrm{w}}\right)$ of amylopectin as confirmed by the SEC-MALLS-RI analysis (Figure 
of the amylose in the tapioca starch. Accordingly, the elution volume of amylopectin moved from $13 \mathrm{~mL}$ to $12.5 \mathrm{~mL}$ indicating an increase in $\mathrm{M}_{\mathrm{w}}$ and using the ASTRA software. Mw of amylopectin (Peak 1) and amylose (Peak 2) was calculated using the ASTRA software (Table 1). It can be seen that Mw of NTS amylopectin significantly increases from $2.486 \times 10^{7} \mathrm{Da}$ to $3.214 \times 10^{7} \mathrm{Da}$ in MTS. Besides, the Mw of amylose decreased from $1.642 \times 10^{7} \mathrm{Da}$ to $0.692 \times 10^{7} \mathrm{Da}$.

These results indicated the transfer of shorter fragments from amylose to amylopectin. However, the significantly decreased $\mathrm{Mw}$ of NTS from $2.872 \times 10^{7} \mathrm{Da}$ to $2.317 \times 10^{7}$ Da may be related to the cyclization reaction. The amylose degraded was not only transferred to amylopectin, but also forming large-ring cyclodextrin. ${ }^{24}$ The amylose content was quantified enzymatically and gradually decreased from $23.5 \%$ to a low level of about $9 \%$ remaining essentially constant after $4 \mathrm{~h}$ (Figure 4C) in agreement with the SEC profile (Figure 4B). Combined with the SEC-MALLS-RI data, chain distribution of amylopectin, and results obtained in previous studies, it was concluded that a broader amylopectin cluster with higher $\mathrm{M}_{\mathrm{w}}$ was formed by the TuaGT modification. ${ }^{34}$

Retrogradation Properties of MTS in Comparison to NTS. The long-term retrogradation of MTS was estimated by

DSC (Table 2, Figure 5). The changes in onset temperature $\left(T_{o}\right)$, peak temperature $\left(T_{p}\right)$, conclusion temperature $\left(T_{c}\right)$ and melting enthalpy $(\Delta \mathrm{H})$ values reflect the crystallinity and composition of starches, indicating the tightness of recrystallized amylose and amylopectin crystals. ${ }^{35}$ The To, Tp, Tc of MTS showed a significant decrease comparing with that of NTS.

(Table 2, Figure 5A), indicating that less hydrogen bonding occurs around the initially generated crystalline structure and a looser crystalline structure was formed which was easier to uncoil, probably due to the reduced amylose content (Figure 4C). ${ }^{36}$ At the same time the $\Delta \mathrm{H}$ of NTS increased significantly with increasing storage time, while MTS showed a much lower $\Delta \mathrm{H}$ compared to NTS. Generally, it is more likely to retrograde for starches which contain more amylose or less branched, longer glucan chains. The content and structure of amylose played a key role in the retrogradation of starch as the crystalline element formed by amylose only is similar to that formed in starch. ${ }^{37}$ Consequently, after modification by 
247 NTS $(1.482 \pm 0.04 \mathrm{~J} / \mathrm{g})$ at $1 \mathrm{~d}$, which means that the long-term retrogradation of tapioca starch was impaired dramatically 248 after short-term retrogradation. According to the results, the long-term retrogradation problem of the starch gel was 249 partially overcome, indicating that the MTS has the potential to be used in some foods with short shelf-life.

Rheological Properties of MTS Comparing with NTS. On the basis of the success in the reduction of long-term retrogradation, the rheological properties of MTS were compared with those of NTS (Figure 6). The firmness of the gel depends on the extent of linear viscoelastic range. ${ }^{38}$ In the present study, the strain independence of storage modulus (G') and loss modulus (G") for all samples, indicated a strain selected for measurement from $0.1 \%$ to $5 \%$ was within a linear viscoelastic range (Figure 6A). Hence, all the following tests were conducted at $1 \%$ strain. Complex viscosity $\left(\eta^{*}\right)$, defined as the ratio of the shear stress over shear rate obtained from a dynamic test, ${ }^{39}$ was detected with angular frequency $(\omega)$ from $0.1 \mathrm{rad} / \mathrm{s}$ to $100 \mathrm{rad} / \mathrm{s}$ (Figure 6B). With the increase of angular frequency, the complex viscosity of NTS and MTS gels experienced an extremely similar decrease from nearly $60 \mathrm{~Pa} \square \mathrm{s}$ to $0.35 \mathrm{~Pa} \square \mathrm{s}$ (data not shown). This decrease in complex viscosity is often referred to as shear thinning, which is also understood as a transition from disordered phase to ordered phase. ${ }^{40}$ Figure $6 \mathrm{C}$. During the heating from $5^{\circ} \mathrm{C}$ to $30^{\circ} \mathrm{C}, \mathrm{G}$ ' and G' with G' of NTS gels at nearly 8.7 Pa and G' of MTS gels at nearly 8.3 Pa (Table 3). Also, the higher value of G' than G', indicates the formation of a "weak-gel" ${ }^{41}$ after storage at $4{ }^{\circ} \mathrm{C}$ for 7 days. Hence, the data above show that the rheological properties of NTS and MTS solutions were highly similar in the investigated temperature range $\left(5-30^{\circ} \mathrm{C}\right)$. contrast, both G' and G', of the MTS solution experienced a dramatic decline of G' from 8.01788 Pa at $30^{\circ} \mathrm{C}$ to 0.98834 Pa at $90^{\circ} \mathrm{C}$ and $\mathrm{G}$ ' from $6.0395 \mathrm{~Pa}$ at $30^{\circ} \mathrm{C}$ to $1.65962 \mathrm{~Pa}$ at $90^{\circ} \mathrm{C}$. Besides, a specific point of intersection (flow point) 
thermal-reversibility was observed in the MTS gel comparing with NTS gel. Thermo-reversibility means that the gel maintains gelation status when the temperature is under gelation temperature and return back to solution status when the temperature is above gelation temperature. As is noted above, after the modification by TuaGT, the amylose fragments were transferred onto non-reducing ends of amylopectin. The degradation of amylose (Figure 4C) leads to decreased amount of double helix formed by amylose which is too strong to be broken. Also, a shorter double helix formed among extended chains of amylopectin can be easily broken compared with the double helix formed by amylose, which possibly explains why the MTS gel was thermo-reversible. ${ }^{43}$ Moreover, it can be concluded that the temperature of the flow point of the MTS solution is similar to that of gelatinization of granular tapioca starch $\left(67.4^{\circ} \mathrm{C}\right) .^{44}$ Hence, the MTS can be processed similarly to the native starch although the MTS was prepared after a gelatinization process.

\section{Acknowledgements}

This work was supported by Natural Science Foundation of Jiangsu Province (grant number BK20170184), National

Natural Science Foundation of China (grant number 31701644), Agricultural Science and Technology Independent

\section{Conflict of interest}

The authors declared that they have no conflicts of interest to this work. 


\section{References}

(1) Farhat, I.; Blanshard, J. M. V.; Mitchell, J. R. The retrogradation of waxy maize starch extrudates: Effects of storage temperature and water content. Biopolymers 2000, 53, 411-422.

(2) Mua, J. P.; Jackson, D. S. Retrogradation and gel textural attributes of corn starch amylose and amylopectin fractions. J. Cereal Sci. 1998, 27, 157-166.

(3) Wang, S.; Li, C.; Copeland, L.; Niu, Q.; Wang, S. Starch retrogradation: a comprehensive review. Compr. Rev. Food Sci. Food Saf. 2015, 14, 568-585.

(4) Fu, Z.; Chen, J.; Luo, S.-J.; Liu, C.-M.; Liu, W. Effect of food additives on starch retrogradation: a review. Starch Stärke 2015, 67, 69-78.

(5) Liu, L.; Yang, M.; Xu, J.; Fan, X.; Gao, W.; Wang, Q.; Wang, P.; Xu, B.; Yuan, J.; Yu, Y. Exploring the mechanism of pullulan delay potato starch long-term retrogradation from the viewpoint of amylopectin chain motion. Int. J. Biol. Macromol. 2020, 145, 84-91.

(6) Li, W.; Li, C.; Gu, Z.; Qiu, Y.; Cheng, L.; Hong, Y.; Li, Z. Relationship between structure and retrogradation properties of corn starch treated with 1,4- $\alpha$-glucan branching enzyme. Food Hydrocoll. 2016, 52, 868-875.

(7) Hernan R. P.; Paul B. S.; Bert L. D. Effect of $\alpha$-Amylases from different sources on the retrogradation and recrystallization of concentrated wheat starch gels: relationship to bread staling. J. Agric. Food Chem. 2004, 52, 59875994.

(8) Yuan, Y.; Jingmin, Z.; Xiaolin, D. Partial $\beta$-Amylolysis retards starch retrogradation in rice products. J. Agric. Food Chem. 2003, 51, 4066-4071.

(9) Biliaderis C G , Prokopowich D J. Effect of polyhydroxy compounds on structure formation in waxy maize starch gels: a calorimetric study. Carbohydr. Polym. 1994, 23, 193-202.

(10) Miao, M.; Jiang, B.; Zhang, T. Effect of pullulanase debranching and recrystallization on structure and digestibility of waxy maize starch. Carbohydr. Polym. 2008, 76, 214-221.

(11) Ranran, C.; Man, L.; Yanfei, W.; Haihua, C.; Junxia, X.; Liu, X.; Lizhong, Q.; Xiliang, B.; Chunrui, S.; Qingjie, S. Retrogradation behavior of debranched starch with different degrees of polymerization. Food Chem. 2019, 297, 125001. (12) Maarel, M. J. E. C. v. d.; Capron, I.; Euverink, G. J. W.; Bos, H. T.; Steeneken, P. A. M. A novel thermoreversible gelling product made by enzymatic modification of starch. Starch - Stärke 2010, 57, 465-472.

(13) Yu, S.; Ma, Y.; Sun, D.-W. Impact of amylose content on starch retrogradation and texture of cooked milled rice during storage. J. Cereal Sci. 2009, 50, 139-144.

(14) Yu, P.; Li, J. R. Molecular cloning, sequence analysis, expression and characterization of the endochitinase gene from Trichoderma sp. in Escherichia coli BL21. World J. Microbiol. Biotechnol. 2008, 24, 2509-2516.

(15) Li, X.; Bai, Y.; Ji, H.; Wang, J.; Cui, Y.; Jin, Z. Functional characterization of tryptophan 437 at subsite +2 in pullulanase from Bacillus subtilis str. 168. Int. J. Biol. Macromol. 2019, 133, 920-928.

(16) Hengen, P. N. Purification of His-Tag fusion proteins from. Trends Biochem. Sci. 1995, 20, 285-286.

(17) Kaper, T.; Talik, B.; Ettema, T. J.; Bos, H.; van der Maarel, M. J. E. C.; Dijkhuizen, L. Amylomaltase of Pyrobaculum aerophilum IM2 produces thermoreversible starch gels. Appl. Environ. Microbiol. 2005, 71, 5098-5106.

(18) Wang, K.; Qi, T.; Guo, L.; Ma, Z.; Gu, G.; Xiao, M.; Lu, L., Enzymatic glucosylation of salidroside from starch by $\alpha$-amylase. J. Agric. Food Chem. 2019, 67, 2012-2019.

(19) Lee, K. Y.; Kim, Y.-R.; Park, K. H.; Lee, H. G., Effects of $\alpha$-glucanotransferase treatment on the thermo-reversibility and freeze-thaw stability of a rice starch gel. Carbohydr. Polym. 2005, 63. 347-354.

(20) Gibson, T. S.; Solah, V. A.; McCleary, B. V. A procedure to measure amylose in cereal starches and flours with concanavalin a. J. Cereal Sci 1997, 25, 111-119.

(21) Chen, L.; Tian, Y.; Bai, Y.; Wang, J.; Jiao, A.; Jin, Z., Effect of frying on the pasting and rheological properties of normal maize starch. Food Hydrocoll. 2017, 77, 85-95. 
Carbohydr. Polym. 2019, 210, 74-72.

(23) Sorndech, W.; Sagnelli, D.; Meier, S.; Jansson, A. M.; Lee, B. H.; Hamaker, B. R.; Rolland-Sabaté, A.; Hebelstrup, K. H.; Tongta, S.; Blennow, A., Structure of branching enzyme- and amylomaltase modified starch produced from welldefined amylose to amylopectin substrates. Carbohydr. Polym. 2016, 152, 51-61.

(24) Willett, J. L.; Millard, M. M.; Jasberg, B. K. Extrusion of waxy maize starch: melt rheology and molecular weight degradation of amylopectin. Polymer 1997, 38, 5983-5989.

(25) Tang, S.-Y.; Yang, S.-J.; Cha, H.; Woo, E.-J.; Park, C.; Park, K.-H. Contribution of W229 to the transglycosylation activity of 4- $\alpha$-glucanotransferase from Pyrococcus furiosus. BBA - Proteins and Proteomics 2006, 1764, $1633-1638$.

(26) Przylas, I., .; Tomoo, K., .; Terada, Y., .; Takaha, T., .; Fujii, K., .; Saenger, W., .; SträTer, N. Crystal structure of amylomaltase from Thermus aquaticus, a glycosyltransferase catalysing the production of large cyclic glucans. J. Mol. Biol. 2000, 296, 873-886.

(27) Jong-Hyun, J.; Tae-Yang, J.; Dong-Ho, S.; Sei-Mee, Y.; Hyun-Chang, C.; Byoung Chul, P.; Cheon-Seok, P.; EuiJeon, W. Structural and functional analysis of substrate recognition by the 250s loop in amylomaltase from Thermus brockianus. Proteins: Struct., Funct., Bioinf. 2011, 79, 633-644.

(28) Barends, T. R. M., Bultema, J. B., Kaper, T., van der Maarel, M. J. E. C., Dijkhuizen, L., Dijkstra, B. W. Three-way stabilization of the covalent intermediate in amylomaltase, an $\alpha$-amylase-like transglycosylase. J. Biol. Chem. 2007, 282, 17242-17249.

(29) Bonch-Osmolovskaya, E. A.; Miroshnichenko, M. L.; Kostrikina, N. A.; Chernych, N. A.; Zavarzin, G. A. Thermoproteus uzoniensis sp. nov., a new extremely thermophilic archaebacterium from Kamchatka continental hot springs. Arch. Microbiol. 1990, 154, 556-559.

(30) Tantanarat, K.; O’Neill, E. C.; Rejzek, M.; Field, R. A.; Limpaseni, T. Expression and characterization of 4- $\alpha-$ glucanotransferase genes from Manihot esculenta Crantz and Arabidopsis thaliana and their use for the production of cycloamyloses. Process Biochem. 2014, 49, 84-89.

(31) Terada, Y. F. K.; Takaha, T.; Okada, S. Thermus aquaticus ATCC 33923 amylomaltase gene cloning and expression and enzyme characterization: Production of cycloamylose. Appl. Environ. Microbiol. 1999, 65, 910-915.

(32) Ao, Z.; Simsek, S.; Zhang, G.; Venkatachalam, M.; Reuhs, B. L.; Hamaker, B. R. Starch with a slow digestion property produced by altering its chain length, branch density, and crystalline structure. J Agric Food Chem. 2007, 55, 4540-4547.

(33) Witt, T.; Doutch, J.; Gilbert, E. P.; Gilbert, R. G. Relations between molecular, crystalline, and lamellar structures of amylopectin. Biomacromolecules 2012, 13, 4273-4282.

(34)Yu, S. F.; Xu, J.; Zhang, Y. C.; Kopparapu, N. K. Relationship between intrinsic viscosity, thermal, and retrogradation properties of amylose and amylopectin. Czech J. Food Sci. 2014, 32, 514-520.

(35) Xiao-Pei, H.; Yao-Yu, X.; Zheng-Yu, J.; Xue-Ming, X.; Han-Qing, C. Effect of single-, dual-, and tripleretrogradation treatments on in vitro digestibility and structural characteristics of waxy wheat starch. Food Chem. 2014, 157, 373-379.

(36) Fredriksson, H.; Silverio, J.; Andersson, R.; Eliasson, A. C.; Åman, P. The influence of amylose and amylopectin characteristics on gelatinization and retrogradation properties of different starches. Carbohydr Polym. 1998, 35, 119-134. (37) Miles, M. J.; Morris, V. J.; Orford, P. D.; Ring, S. G. The roles of amylose and amylopectin in the gelation and retrogradation of starch. Int. J. Food Eng. 2014, 135, 271-81.

(38) Yang, H.; Irudayaraj, J.; Otgonchimeg, S.; Walsh, M. Rheological study of starch and dairy ingredient-based food systems. Food Chem. 2004, 86, 571-578.

(39) Saint-Eve, A.; Martin, N.; Guillemin, H.; Sémon, E.; Guichard, E.; Souchon, I. Flavored yogurt complex viscosity influences real-time aroma release in the mouth and sensory properties. J. Agric. Food Chem. 2006, 54, 7794-7803.

(40) Subramanian, V.; Hoseney, R. C.; Bramelcox, P. Shear thinning properties of sorghum and corn starches. Cereal Chem. 1994, 71, 272-275..

(41) Morris; R., E. Ordered conformation of xanthan in solutions and "weak gels": single helix, double helix - or both? 
384 Food Hydrocoll. 2017, 86, 18-25.

385 (42) Tashiro, A.; Hasegawa, A.; Kohyama, K.; Kumagai, H.; \& Kumagai, H. Relationship between the rheological 386 properties of thickener solutions and their velocity through the pharynx as measured by the ultrasonic pulse doppler 387 method. Biosci. Biotechnol. Biochem. 2010, 74, 1598-1605.

388 (43) Ring, S. G.; Colonna P.; I'Anson, K. J.; Kalichevsky, M. T.; Miles, M. J.; Morris, V. J.; Orford, D. P. The gelation 389 and crystallisation of amylopectin. Carbohydr. Res. 1987, 162, 277-293. (44) Cooke, D.; Gidley, M. J. Loss of crystalline and molecular order during starch gelatinisation: origin of the enthalpic transition. Carbohydr. Res. 1992, 227, 103-112. 
Figure 1 Bioinformatics analysis of TuaGT. (A) Comparison of amino acid sequence in three characteristic conserved regions (I, II and III) and the $250 \mathrm{~s}$ loop of different $4 \alpha \mathrm{GT}$. The three putative catalytic residues were emphasized in red. $4 \alpha \mathrm{GT}$ from Thermoproteus uzoniensis (WP_013679179.1, putative) 4aGT from Thermanaerothrix daxensis (WP_054521162.1, putative), 4aGT from Meiothermus ruber (WP_013013404.1, putative), 4aGT from Oceanithermus profunsus (WP_013457929.1, putative), 4aGT from

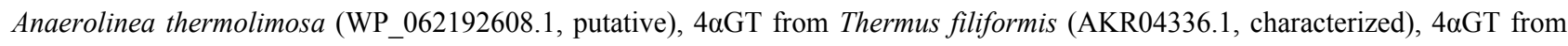
Eubacterium sp. CAG:76 (CDF09158.1, characterized), 4aGT from Eubacterium sp. CAG:38 (CDE37197.1, characterized), 4aGT from Eubacterium sp. CAG:192 (CDB13236.1, characterized), 4aGT from [Eubacterium] eligens ATCC 27750 (ACR71403.1,

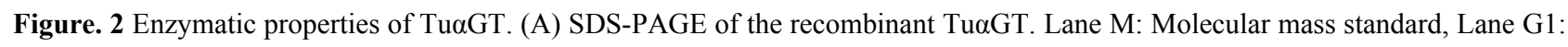



curve: reaction mixture with maltotetraose as substrate. (B) Product produced by TuaGT hydrolysed by $\alpha$-amylase and $\alpha$-glucosidase. Black curve: standard mixture (G1 to G7 represent glucose to maltoheptaose); red curve: product hydrolysed by $\alpha$-amylase and $\alpha$ -

421 glucosidase using reaction mixture with glucose as substrate of TuaGT; blue curve: product hydrolysed by $\alpha$-amylase and $\alpha$-glucosidase using reaction mixture with maltose as substrate of Tu $\alpha \mathrm{GT}$; green curve: product hydrolysed by $\alpha$-amylase and $\alpha$-glucosidase using reaction mixture with maltotriose as substrate of TuaGT; purple curve: product hydrolysed by $\alpha$-amylase and $\alpha$-glucosidase using reaction mixture with maltotetraose as substrate of TuaGT.

Figure. 4 The changes of tapioca starch structure by TuaGT modification. (A) difference value in chain length distribution using HPAEC-PAD, the bars above zero indicate a decline of the content of chains with this DP in the MTS compared with NTS, the bars below zero indicate an increase of the content of chains with this DP in the MTS compared with NTS. (B) Molecular weight using reaction mechanism of $4 \alpha \mathrm{GT}$ on amylose and amylopectin.

Figure. 5 Retrogradation properties of NTS and MTS. (A) Retrogradation thermograms of NTS and MTS with different storage time. (B) Melting enthalpy $(\Delta \mathrm{H})$ of NTS (black solid column) and MTS (white open column) with different storage time. 
441 Table 1 Weight-average molecular weight of tapioca starch during modification

442 a Tests were performed in triplicate. Mean \pm standard deviation values in the same column for each sample followed by different letters 443 are significantly different $(\mathrm{p}<0.05)$ by Duncan's test.

\begin{tabular}{cccc}
\hline \multirow{2}{*}{ Sample } & \multicolumn{3}{c}{$\mathrm{M}_{\mathrm{w}} \times 10^{7}(\mathrm{~g} / \mathrm{mol})$} \\
\cline { 2 - 4 } & Peak 1 (amylopectin) & Peak 2 (amylose) & Peak 1 + Peak2 \\
\hline NTS & $2.486 \pm 0.191 \mathrm{~b}$ & $1.642 \pm 0.105 \mathrm{a}$ & $2.872 \pm 0.281 \mathrm{a}$ \\
MTS-1 h & $2.749 \pm 0.162 \mathrm{~b}$ & $1.331 \pm 0.149 \mathrm{~b}$ & $2.716 \pm 0.147 \mathrm{ab}$ \\
MTS -8 h & $3.214 \pm 0.213 \mathrm{a}$ & $0.692 \pm 0.092 \mathrm{c}$ & $2.317 \pm 0.172 \mathrm{~b}$ \\
\hline
\end{tabular}


445 Table 2 The retrogradation properties (onset temperature (To), peak temperature (Tp), conclusion temperature (Tc) and melting 446 enthalpy $(\Delta \mathrm{H})$ ) of NTS and MTS stored from $1 \mathrm{~d}$ to $21 \mathrm{~d}$ measured by DSC

447 a Tests were performed in triplicate. Mean \pm standard deviation values in the same column for each sample followed by different letters 448 are significantly different $(\mathrm{p}<0.05)$ by Duncan's test.

\begin{tabular}{ccccc}
\hline Sample & $\mathrm{T}_{\mathrm{o}}\left({ }^{\circ} \mathrm{C}\right)$ & $\mathrm{T}_{\mathrm{p}}\left({ }^{\circ} \mathrm{C}\right)$ & $\mathrm{T}_{\mathrm{c}}\left({ }^{\circ} \mathrm{C}\right)$ & $\Delta \mathrm{H}(\mathrm{J} / \mathrm{g})$ \\
\hline NTS-1 d & $49.87 \pm 0.01 \mathrm{a}$ & $51.43 \pm 0.02 \mathrm{~b}$ & $62.92 \pm 0.04 \mathrm{c}$ & $1.482 \pm 0.04 \mathrm{~g}$ \\
MTS-1 d & $48.56 \pm 0.04 \mathrm{~b}$ & $50.97 \pm 0.01 \mathrm{~d}$ & $61.04 \pm 0.05 \mathrm{~d}$ & $0.851 \pm 0.07 \mathrm{~h}$ \\
NTS-7 d & $48.14 \pm 0.12 \mathrm{c}$ & $51.99 \pm 0.07 \mathrm{a}$ & $64.21 \pm 0.021 \mathrm{a}$ & $2.641 \pm 0.17 \mathrm{e}$ \\
MTS-7 d & $46.39 \pm 0.09 \mathrm{~d}$ & $50.12 \pm 0.04 \mathrm{e}$ & $63.41 \pm 0.08 \mathrm{~b}$ & $1.876 \pm 0.07 \mathrm{f}$ \\
NTS-14 d & $44.19 \pm 0.06 \mathrm{e}$ & $51.43 \pm 0.11 \mathrm{~b}$ & $64.17 \pm 0.18 \mathrm{a}$ & $4.892 \pm 0.06 \mathrm{~b}$ \\
MTS-14 d & $42.27 \pm 0.07 \mathrm{~g}$ & $50.86 \pm 0.04 \mathrm{~d}$ & $63.34 \pm 0.04 \mathrm{~b}$ & $3.162 \pm 0.01 \mathrm{~d}$ \\
NTS-21 d & $43.96 \pm 0.01 \mathrm{f}$ & $52.14 \pm 0.09 \mathrm{a}$ & $62.98 \pm 0.06 \mathrm{c}$ & $6.817 \pm 0.07 \mathrm{a}$ \\
MTS-21 d & $41.14 \pm 0.04 \mathrm{~h}$ & $51.22 \pm 0.15 \mathrm{c}$ & $60.12 \pm 0.02 \mathrm{e}$ & $4.274 \pm 0.12 \mathrm{c}$ \\
\hline
\end{tabular}


450 Table 3 The storage modulus (G') and loss modulus (G') of NTS and MTS at temperature ramp from $5^{\circ} \mathrm{C}$ to $90^{\circ} \mathrm{C}$

451 a Tests were performed in triplicate. Mean \pm standard deviation values in the same column for each sample followed by different letters 452 are significantly different $(\mathrm{p}<0.05)$ by Duncan's test.

\begin{tabular}{ccccc}
\hline Temperature $\left({ }^{\circ} \mathrm{C}\right)$ & G'-NTS $(\mathrm{Pa})$ & G $^{\prime \prime}-\mathrm{NTS}(\mathrm{Pa})$ & G'$^{\prime}-\mathrm{MTS}(\mathrm{Pa})$ & G"$^{\prime \prime}-\mathrm{MTS}(\mathrm{Pa})$ \\
\hline 5 & $8.77 \pm 0.2 \mathrm{a}$ & $5.57 \pm 0.14 \mathrm{a}$ & $8.32 \pm 0.21 \mathrm{a}$ & $6.16 \pm 0.23 \mathrm{a}$ \\
10 & $8.67 \pm 0.22 \mathrm{a}$ & $5.49 \pm 0.23 \mathrm{a}$ & $8.32 \pm 0.19 \mathrm{a}$ & $6.16 \pm 0.22 \mathrm{a}$ \\
15 & $8.65 \pm 0.18 \mathrm{a}$ & $5.48 \pm 0.22 \mathrm{a}$ & $8.31 \pm 0.12 \mathrm{a}$ & $6.15 \pm 0.16 \mathrm{a}$ \\
20 & $8.64 \pm 0.19 \mathrm{a}$ & $5.44 \pm 0.16 \mathrm{ab}$ & $8.28 \pm 0.14 \mathrm{a}$ & $6.07 \pm 0.12 \mathrm{ab}$ \\
25 & $8.61 \pm 0.17 \mathrm{a}$ & $5.42 \pm 0.12 \mathrm{ab}$ & $8.27 \pm 0.23 \mathrm{a}$ & $6.07 \pm 0.02 \mathrm{ab}$ \\
30 & $8.57 \pm 0.14 \mathrm{a}$ & $5.35 \pm 0.02 \mathrm{ab}$ & $8.01 \pm 0.22 \mathrm{a}$ & $6.04 \pm 0.12 \mathrm{ab}$ \\
35 & $8.56 \pm 0.22 \mathrm{a}$ & $5.27 \pm 0.12 \mathrm{ab}$ & $7.5 \pm 0.18 \mathrm{~b}$ & $5.72 \pm 0.11 \mathrm{~b}$ \\
40 & $8.47 \pm 0.21 \mathrm{a}$ & $5.18 \pm 0.11 \mathrm{abc}$ & $6.99 \pm 0.19 \mathrm{c}$ & $5.36 \pm 0.14 \mathrm{c}$ \\
45 & $8.33 \pm 0.19 \mathrm{ab}$ & $5.07 \pm 0.2 \mathrm{abcd}$ & $6.34 \pm 0.17 \mathrm{~d}$ & $4.89 \pm 0.23 \mathrm{~d}$ \\
50 & $8.14 \pm 0.12 \mathrm{~b}$ & $4.96 \pm 0.22 \mathrm{bcd}$ & $5.49 \pm 0.14 \mathrm{e}$ & $4.51 \pm 0.22 \mathrm{e}$ \\
55 & $7.9 \pm 0.14 \mathrm{bc}$ & $4.86 \pm 0.18 \mathrm{cde}$ & $4.67 \pm 0.22 \mathrm{f}$ & $3.95 \pm 0.18 \mathrm{f}$ \\
60 & $7.7 \pm 0.23 \mathrm{c}$ & $4.74 \pm 0.14 \mathrm{de}$ & $3.74 \pm 0.12 \mathrm{~g}$ & $3.64 \pm 0.19 \mathrm{f}$ \\
65 & $7.48 \pm 0.13 \mathrm{~cd}$ & $4.59 \pm 0.22 \mathrm{e}$ & $2.98 \pm 0.23 \mathrm{~h}$ & $3.21 \pm 0.22 \mathrm{~g}$ \\
70 & $7.31 \pm 0.16 \mathrm{de}$ & $4.59 \pm 0.21 \mathrm{e}$ & $2.22 \pm 0.12 \mathrm{i}$ & $2.74 \pm 0.18 \mathrm{~h}$ \\
75 & $7.21 \pm 0.12 \mathrm{de}$ & $4.49 \pm 0.19 \mathrm{e}$ & $1.71 \pm 0.06 \mathrm{j}$ & $2.4 \pm 0.14 \mathrm{i}$ \\
80 & $7.1 \pm 0.12 \mathrm{def}$ & $4.52 \pm 0.12 \mathrm{e}$ & $1.25 \pm 0.06 \mathrm{k}$ & $2.07 \pm 0.09 \mathrm{ij}$ \\
85 & $6.95 \pm 0.11 \mathrm{ef}$ & $4.53 \pm 0.14 \mathrm{e}$ & $1.08 \pm 0.05 \mathrm{k}$ & $1.79 \pm 0.08 \mathrm{jk}$ \\
90 & $6.83 \pm 0.12 \mathrm{f}$ & $4.5 \pm 0.12 \mathrm{e}$ & $0.99 \pm 0.06 \mathrm{k}$ & $1.66 \pm 0.09 \mathrm{k}$ \\
\hline
\end{tabular}


(A)

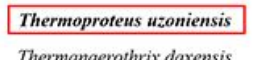

Thermus filiformis

Meiothermus ruber

Oceanithermus profimsus

Anaerolinea thermolimose

Eubacterium sp. CAG:76

Eubacterium sp. CAG:38

Eubacterium sp. CAG:192

Eubacterium sp. CAG:192

\begin{tabular}{|c|c|c|c|c|}
\hline NCBI number & 250s loop & Conserved region I & Conserved region II & Conserved region III \\
\hline WP_013679179.1 & 232 VAG VPPDYFSETGQ & $280 \mathrm{R} \mathrm{L}$ & GY I T P & 377 Y T G \\
\hline WP_054521162.1 & 246 V A G V P P D Y F S P T G Q & $292 \mathrm{R} \mathrm{L}$ & GV I T P & 391 Y T G \\
\hline AKR04336.1 & 230 VAG VPPDYFSETGQ & HF R G & LGVITE & 377 Y TG \\
\hline WP_013013404.1 & 244 V A G V P P D Y F S E T G Q & HF R G & I T P & VDT \\
\hline WP_013457929.1 & 244 V A G V P P D Y F S P T G Q & 292 R I & G L I T P & NDT \\
\hline WP_062192608.1 & 247 VAG VPPDYF SETGQ & HFR G & GE I T P & DT \\
\hline CDF09158.1 & 287 VAG VPPDAFSDMGQ & HFLG & LGVCMP & $432 \mathrm{YG} \mathrm{G}^{-1}$ \\
\hline CDE37197.1 & 291 VA G V P P D AF S D L GQ & $339 \mathrm{R} \mathrm{I}$ & DLGVLVP & $436 \mathrm{Y} \mathrm{G} \mathrm{G}^{-}$ \\
\hline CDB13236.1 & 246 V A G V P P D AF S D L GQ & HF I G & DLG IKMP & NDT \\
\hline ACR71403.1 & 286 VAG VPPDAF S DAGQ & HFI G & LGVEV P & $431 \mathrm{YG}$ \\
\hline
\end{tabular}

(B)

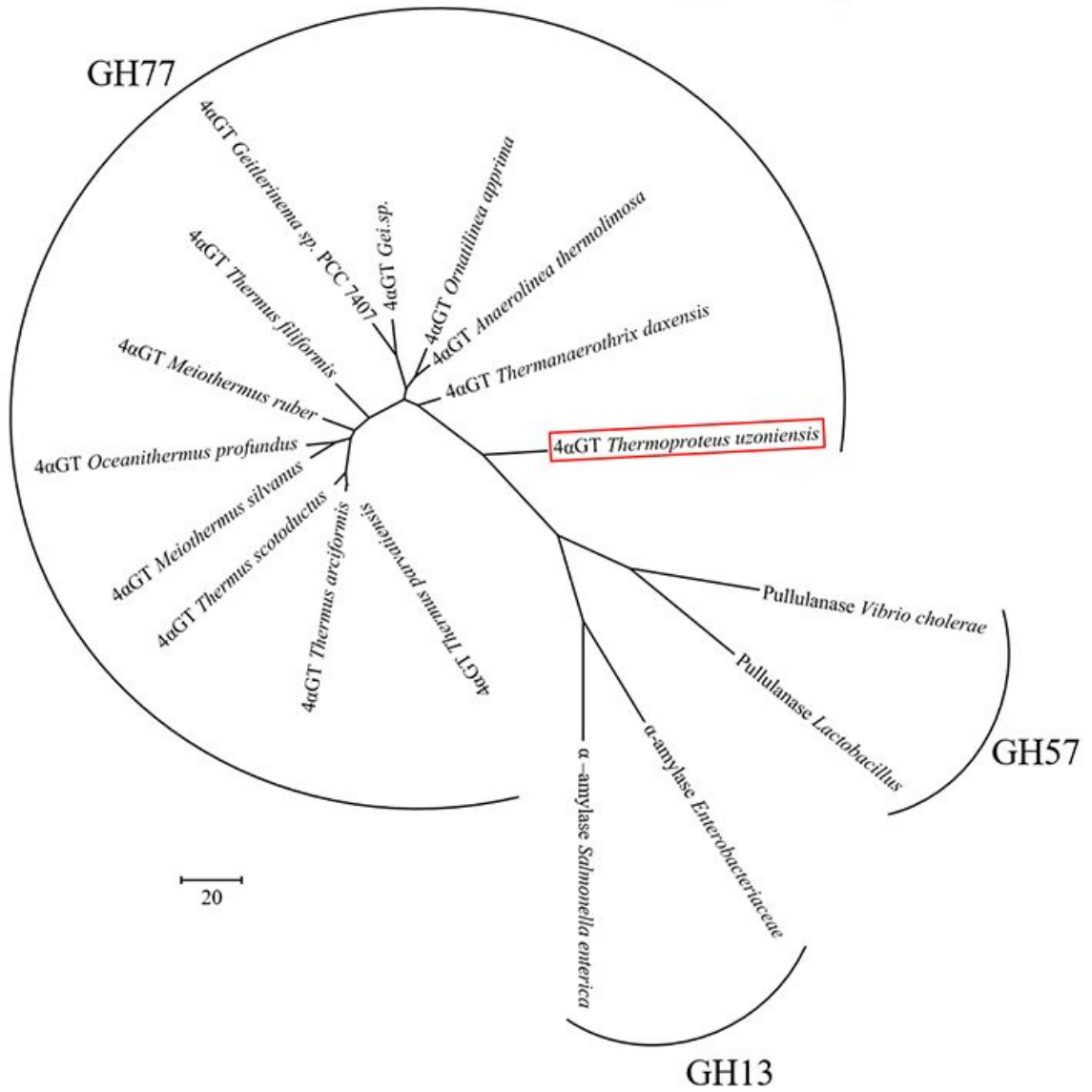

Figure 1 Bioinformatics analysis of TuaGT. 

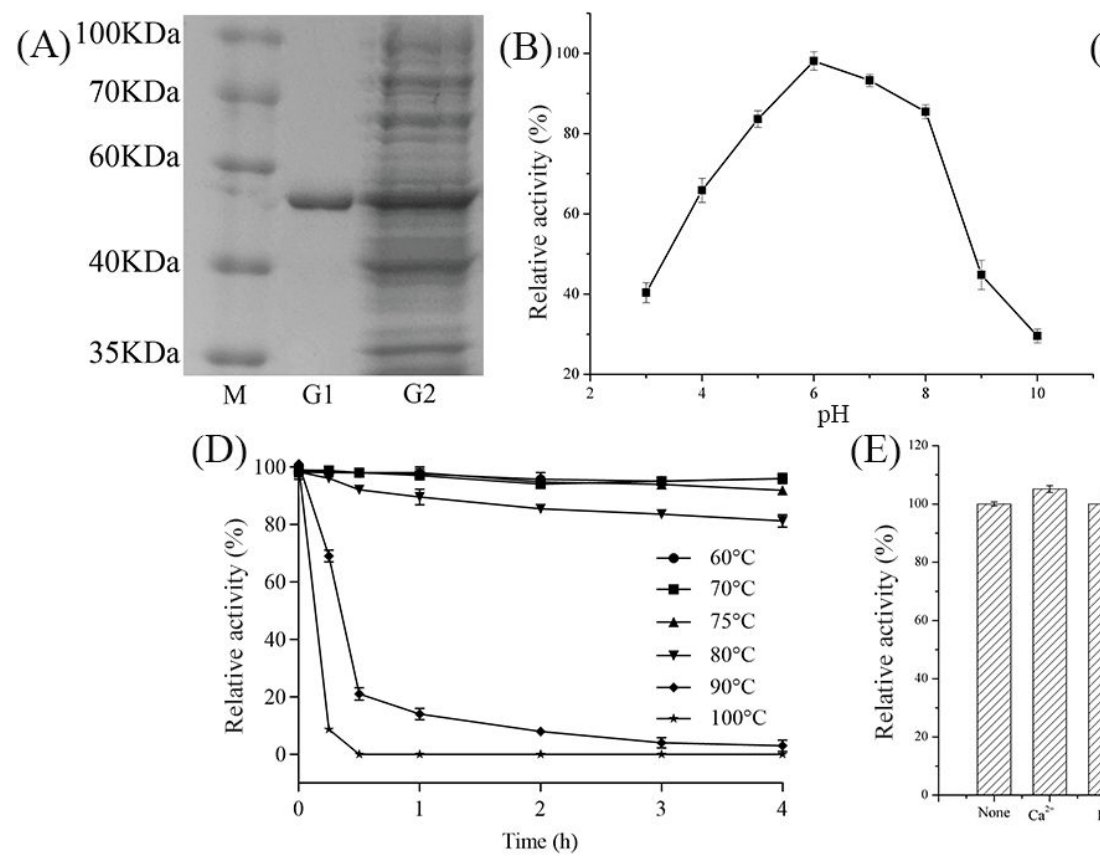

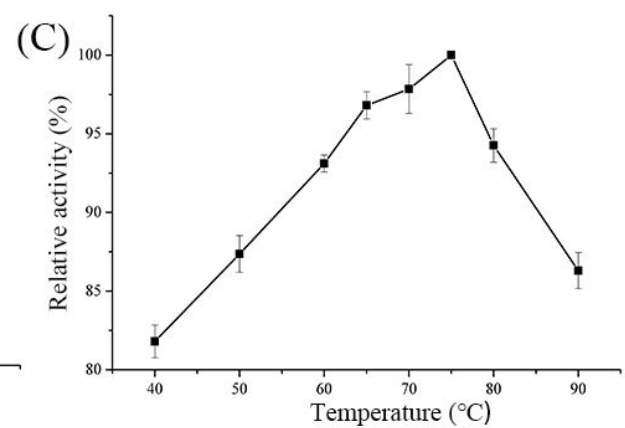

(E)

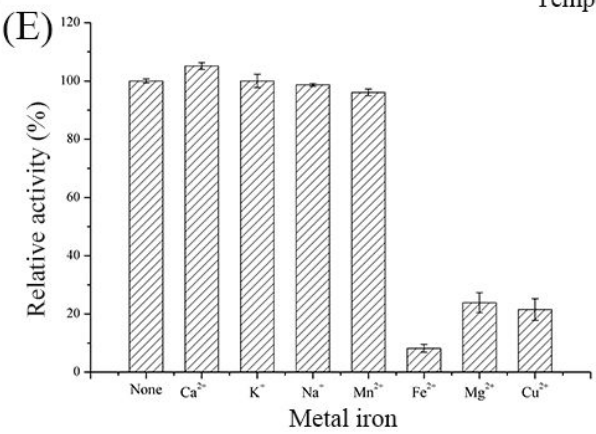

Figure. 2 Enzymatic properties of TuaGT. 

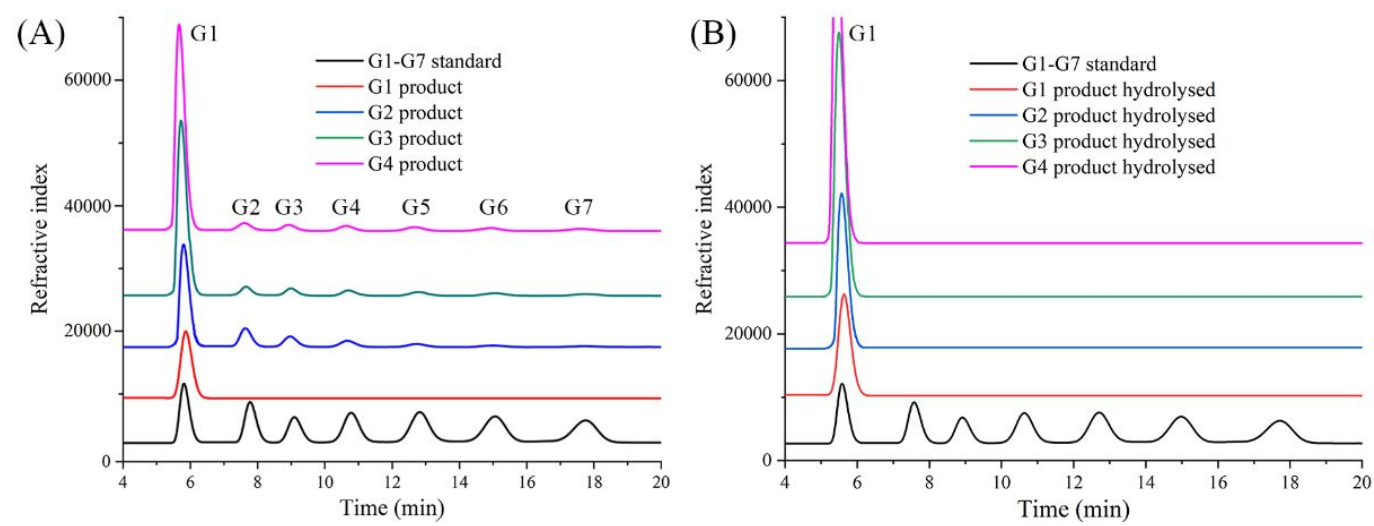

Figure. 3 Identification of disproportion activity of TuaGT. 

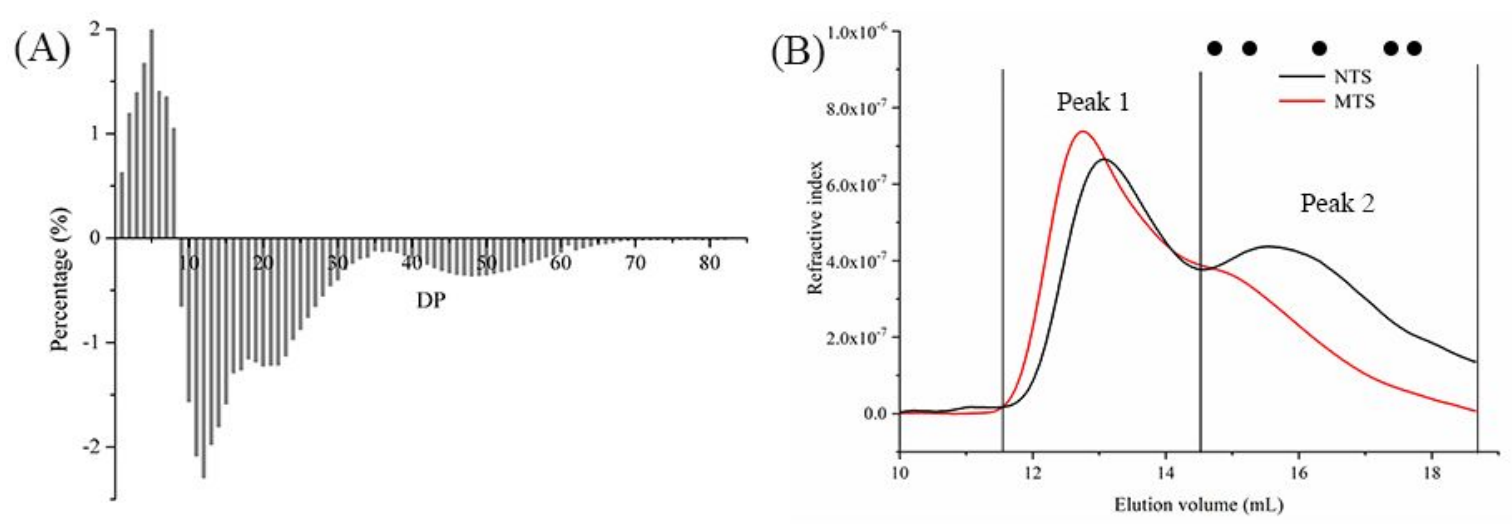

(C)

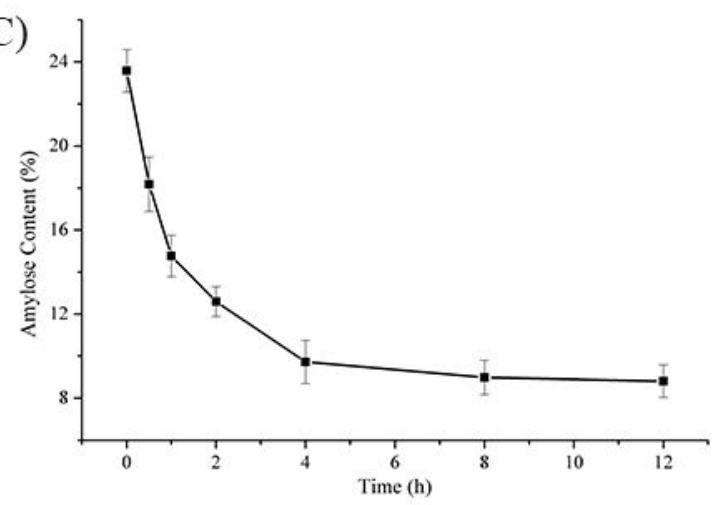

(D)

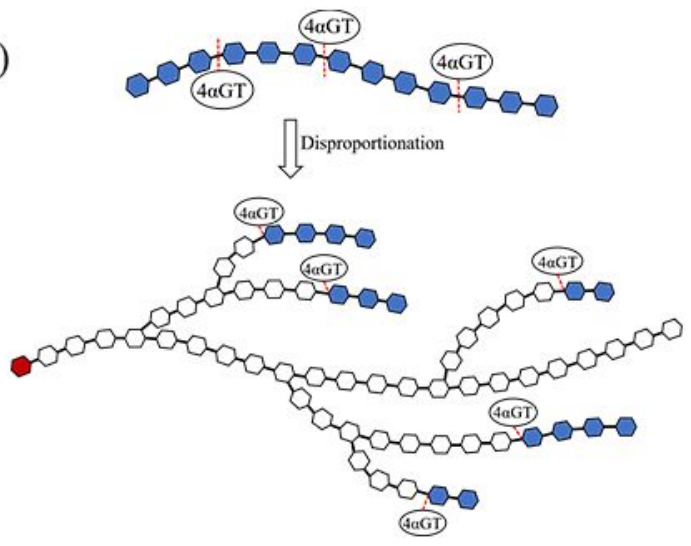

Figure. 4 The changes of tapioca starch structure by TuaGT modification. 

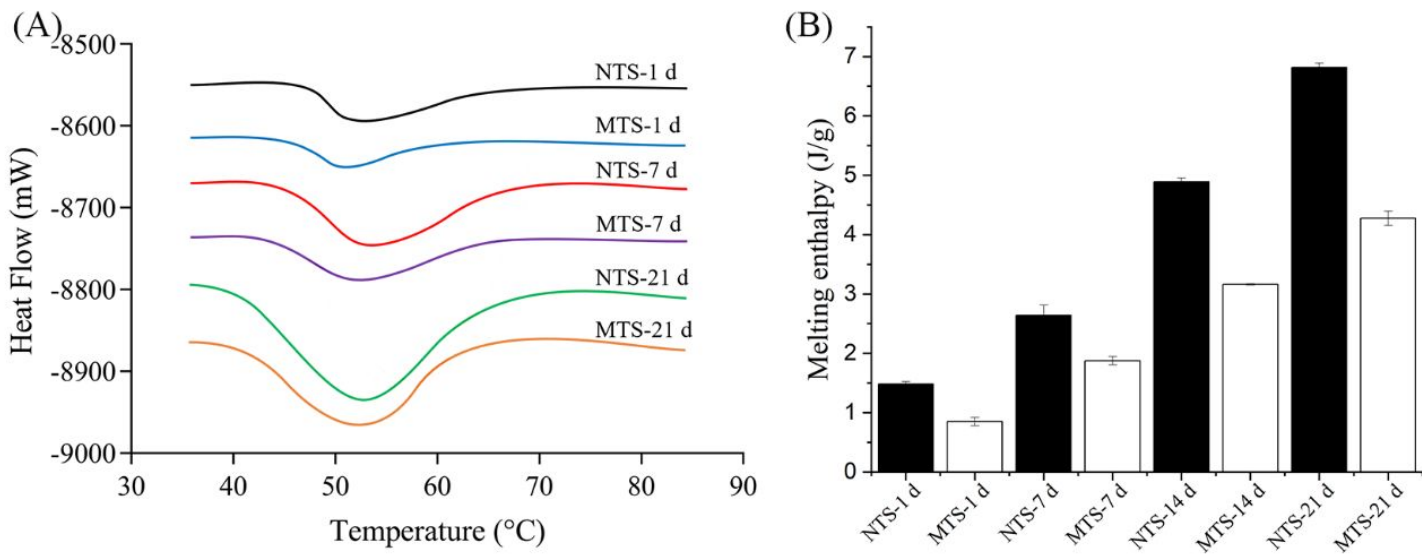

466

Figure. 5 Retrogradation properties of NTS and MTS. 

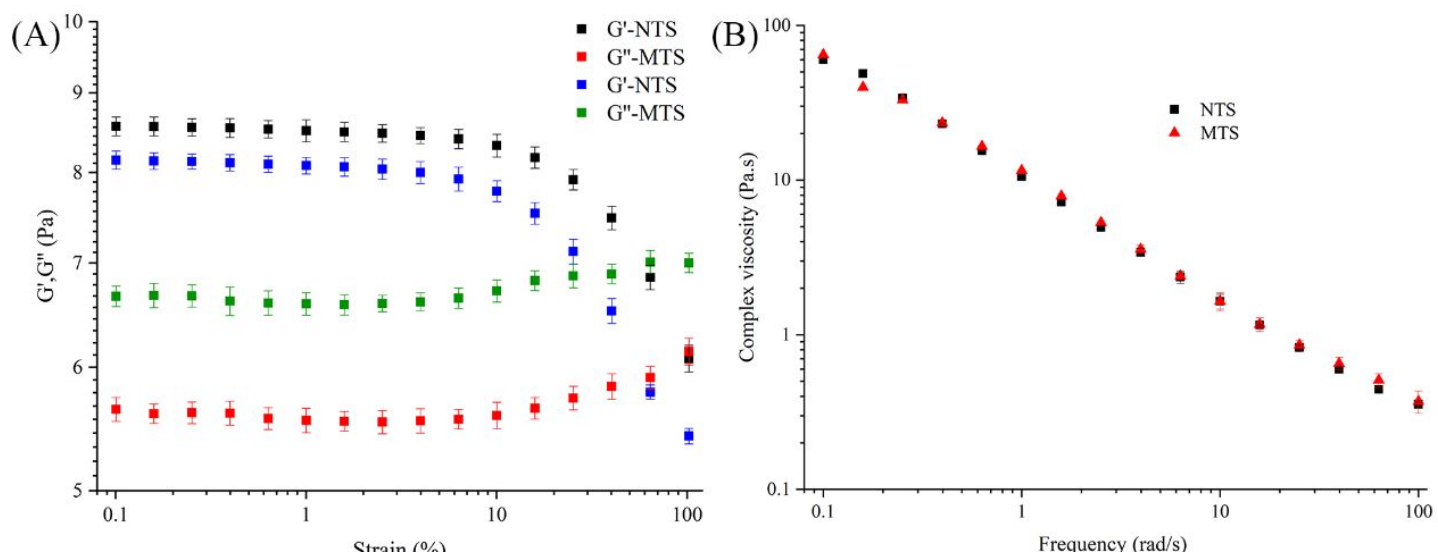

(C)

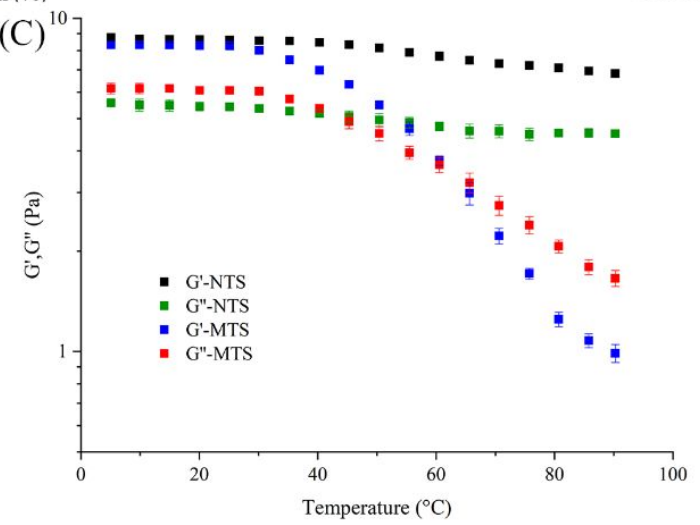

Figure. 6 Comparison of rheological properties of MTS and NTS. 


\section{$472 \quad$ TOC graphic}

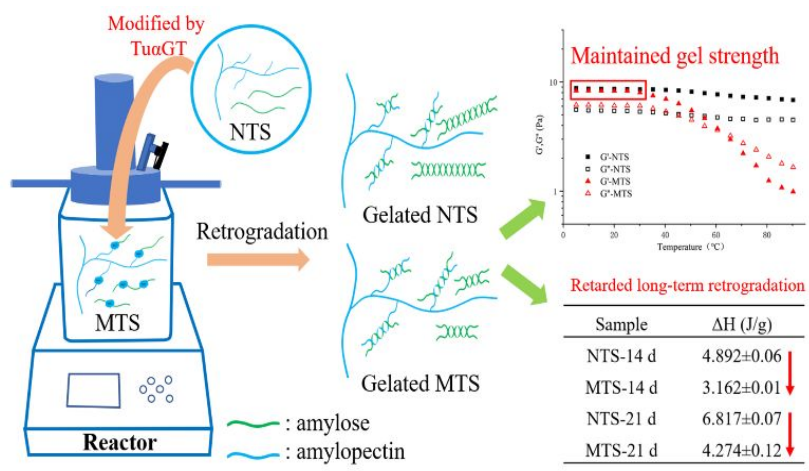




\section{Highlights}

476 1. A novel thermophilic 4- $\alpha$-glucanotransferase was characterized.

477 2. The structure of tapioca starch was dramatically modified by TuaGT.

478 3. The short-term gelation ability and gel strength of tapioca starch was maintained after modification.

479 4. Long-term retrogradation of modified starch was partially retarded. 